\title{
Vision 2020 - Right to Sight
}

\section{A látás védelmét szolgáló húsz éves globális program}

\author{
PAJOR EMESE
}

pajor.emese@,barczi.elte.hu

\begin{abstract}
ABSZTRAKT
A cikk bemutatja a WHO Vision 2020 program hátterét, a program megvalósulásához vezető utat. Betekintést nyújt a látássérülések kórokainak és prevalenciájának azon változásaiba, amelyek a program hatására történtek világszerte. A húsz éves akció során az elkerülhető vakság és látáskárosodás megelőzésére szervezett cselekvési tervek nagymértékben hozzájárultak a program sikeréhez.

A nemzetközi eredmények mellett a cikk röviden bemutatja a hazai kutatásokat, programokat és eredményeket is. Az elkerülhető vakság felszámolására tett küzdelmek 2020-ra azonban nem fejeződtek be. Új fókuszpontokkal, növekvő globális népességgel szembenézve tovább folytatódnak a vakság és a látássérülés felszámolására tett lépések.
\end{abstract}

Kulcsszavak: WHO, Vision 2020 - Right to Sight, World Riport of Vision, vakság, látássérülés, megelőzés

\section{MIT JELENT A VISION 2020?}

A Vision 2020 - Right to Sight (Vision 2020 - a látáshoz való jog) elnevezésű világméretű kezdeményezés célja, hogy 2020-ig felszámolásra kerüljön a „megelőzhető” és a „kezelhető” vakság. A WHO (Egészségügyi Világszervezet) több mint húsz - szemészeti ellátást biztosító, és a látássérülés prevenciójával foglalkozó - nemzetközi szervezettel közösen, 1999. február 18-án indította el ezt a nagyszabású programot, melyet az IAPB (International Agency for the Prevention of Blindness - Nemzetközi Vakságmegelőző Intézet) szervezete fog össze.

A Vision 2020 program három fő cél megvalósítását irányozza elő világszinten:

- Azon programok számának növelését, melyek a vakság okait és megelőzésének lehetőségeit mutatják be az érintettek körében.

- A vakság megelőzését és a látássérülés kezelését lehetővé tevő erőforrások felkutatását és biztosítását.

- Nemzetközi Programok révén a Vision 2020 három alapvető (fö) stratégiája tervezésének, fejlesztésének és végrehajtásának elősegítését.

A fő stratégiák: 1) Betegségek elleni védekezés: azon speciális programok segítése, amelyek a vakság fő okainak visszaszorítását irányozzák; 2) Humán erőforrás fejlesztés: a szemész szakorvosok és a látással foglalkozó egyéb szakemberek továbbképzésének támogatása; 3 ) Infrastrukturális és technológiai fejlesztés: a szemészeti ellátás elérhetőségének és hozzáférhetőségének támogatása (World Health Organization, 2010b). 


\section{ELŐZMÉNYEK}

A WHO a vakság felszámolására már az 1950-es évek kezdetétől tett erőfeszítéseket. Ebben az időszakban az elsődleges cél, a trachoma ${ }^{1}$ visszaszorítása, sőt megszüntetése volt, így számtalan kutatást végeztek a trachoma prevenciójának és gyógyításának kérdéskörében. Ezek a programok elsősorban a hiperendémiás zónákban futottak, vagyis a Közel-Kelet országaiban, a dél-kelet ázsiai és nyugat-óceániai régiókban. A trachoma kezelésére 1\%-os tetraciklin tartalmú széles spektrumú antibiotikumos szemcseppet alkalmaztak. Bár a védekezés sikeres volt, vagyis a trachoma kis mértékben visszaszorult, azonban hosszú távon nem tudták fenntartani a program eredményeit.

A vakság epidemiológiai okainak, továbbá azok nagyságának és mintázatának első globális adatbázisát 1972-ben, a Twenty-fifth World Health Assembly (Egészségügyi Világszervezet 25. Közgyűlése) vizsgálatai alapján állították össze.

1975-ben - a WHO közremúködésével - megalakult az International Agency for the Prevention of Blindness (IAPB) (Nemzetközi Vakságmegelőró Ügynökség), melyet további kezdeményezések követtek, mint 1976-ban az Egészségügyi Világnap témája, mely a „Foresight Prevents Blindness” („Az előrelátás megelőzi a vakságot”) címet kapta. Az IAPB alapító szervezetei közé tartozott az International Council of Ophthalmology (Ophthalmologusok Nemzetközi Tanácsa), a World Council for the Welfare of the Blind (később World Blind Union - Vakok Világszövetsége), továbbá két civil szervezet. Ezekre a korai partnerségekre, illetve különösen a nemzetközi civil szervezetek hatékony együttműködéseire a Vision 2020 program előfutáraiként is tekinthetünk. A különböző programok közül kiemelendő a WHO egyik nagyon jelentős projektje, az 1974-ben indított Onchocerciasis Control Programme (OCP) (Folyami Vakság Ellenőrző Program), mely hét nyugat-afrikai országban vállalta az onchocerciasis (folyami vakság) ${ }^{2}$ nevű szembetegség prevalenciájának meghatározását, illetve a betegség visszaszorítását (WHO, 1995; WHO, 1999). Az OCP projekt a WHO, a Világbank, az ENSZ Fejlesztési Programja, valamint több mint 20 ország közös finanszírozásával valósult meg. A nemzetközi együttműködésnek köszönhetően a folyami vakság felszámolása további kontinenseken is megvalósulhatott. 1992-ben létrejött az Onchocerciasis Elimination Programme for the Americas (OEPA), mely az amerikai kontinensen volt hivatott felszámolni a betegséget. 1995-ben Afrikában kezdtek hasonló programot (African Programme for Onchocerciasis Control (APOC)) (African Programme for Onchocerciasis Control, 1996; Benton, 1998). A trachoma visszaszorítására 1996ban indult újabb WHO projekt (WHO Alliance for the Global Elimination of Trachoma by the year 2020 (GET2020) (WHO .) A nemzetközi kooperációk során irányelvek megfogalmazása, szaktanácsadás, infrastrukturális és technológiai együttműködések valósultak meg (Resnikoff \& Ramachandra, 2001).

1 Trachoma: a Chlamydia trachomatis baktérium által okozott fertőző betegség. A fertőzés következtében a szemhéj belső felülete durva tapintásúvá válik. Az eldurvulás következménye lehet a szemben fellépő fájdalom, a szemek külső felszíne vagy a szaruhártya lebomlása, illetve súlyos esetben akár vakság is (Süveges, 2010).

2 Onchocerciasis: az Onchocerca volvulus nevű fonálféregfajjal való fertőzöttség kezelés nélkül évekkel a megfertôződés után vakságot okozhat. A kifejlett féreg a bőrben és a subcután szövetben betokosodik. A nőstény nagymennyiségű microfilariát választ ki, amelyek eljutnak a szembe. Az élő filariák láthatók az elülső csarnokban (Süveges, 2010). 
A programok beindításához megfelelő mennyiségű és minél pontosabb szemészeti adatra, információra volt szükség. 1975-ben a becsült adatok szerint 28 millió vak személy élt a világon (Thylefors et al., 1995). Az adatgyüjtés egységesítésére a WHO 1978-ban sztenderdizált irányelvet és protokollt dolgozott ki és adott közre, majd egyszerűsített sztenderd protokollt fejlesztett ki a trachoma és a gyermekkori vakság meghatározásához. Ebben az évben a WHO Vakság Megelőzési Programja (WHO Programme for the Prevention of Blindness (PBL)) már szélesebb körben kezdett foglalkozni a vakság prevenciójával, mivel a trachoma mellett több olyan szemészeti kórformát is megnevezett, amelyek a '70-es években a vakság, vagy súlyos fokú látássérülés kialakulását eredményezhették. Így került be a megelőzési programba az onchocerciasis (folyami vakság), a xerophthalmia (nagymértékű szemszárazság) ${ }^{3}$ és a cataracta (szürkehályog) ${ }^{4}$ szembetegségek visszaszorításának kérdése. A PBL munkájának köszönhető, hogy az 1978. szeptember 6-12. között, Almatiban (Kazahsztán) megtartott International Conference on Primary Health Care (Egészségügyi Alapellátás Nemzetközi Konferencia) nevű tanácskozáson a szemészeti alapellátást az egészségügyi alapellátás szerves részeként fogadták el.

A vakság és látássérülés világszintű előfordulására vonatkozó első megbízható adatok 1993-ban jelentek meg WHO Global Database on Blindness and Visual Impairment (WHO Globális Adatbázis a Vakságról és a Látássérülésről) címen, mely a Világbank számára hivatalos kiindulópontot jelentett a globális megelőző programok finanszírozásához. Az eredmények, miszerint a vak személyek becsült száma a világon megközelítőleg 38 millió, a látássérült személyeké majdnem 110 millió volt (az 1990es világnépességi adatok alapján), sokkolóan hatottak és nagyfokú aggodalomra adtak okot (Thylefors et al., 1995). A további adatelemzések egy vészjósló jövőképet körvonalaztak. Ezek szerint néhány év alatt a világ népességnövekedése a látássérült személyek számának nagymértékủ emelkedését eredményezi. Az akkori számítások alapján 1996-ra a vakság elérheti a 45 millió, a látássérülés a 135 millió főt. Úgy számolták, hogy évente legalább 1-2 millió, de akár 7 millió fővel is növekedhet világszerte a vak személyek száma. A vakságról megállapítást nyert, hogy a vak emberek 90\%-a az alacsony jövedelmú országokban él, továbbá, hogy a vakság 80\%-a megelőzhető lenne. Az adatbázisból továbbá az is kiderült, hogy a vakság aránytalanul magas az időskorú populáció körében, ami a demográfiai tendenciák és az időskori populáció növekedésével a vak és a látássérült emberek számának nagyfokú emelkedését vetítette elő. A Vision 2020 - A látáshoz való jog nevű program indítása egyre sürgetőbb kérdéssé vált. Az 1980-as évek közepére a WHO vakságmegelőzési programjába több mint 50 ország kapcsolódott be. Bár ez a szám 1998-ra több mint 110-re bővült, a PBL célja az ezredfordulón az volt, hogy a WHO minden olyan tagállama részt vegyen a programban, ahol a vakság és a látássérülés kérdése jelentős szerepet tölt be a közegészségügyben (Resnikoff \& Pararajasegaram, 2001).

Xerophthalmia: a cornea és a conjunctiva túlzott szárazsága, amelyek így elvesztik fényüket és elszarusodnak; lokális betegség vagy szisztémás A-vitamin hiány következménye lehet (Süveges, 2010).

4. Cataracta: a szürkehbályog a szemlencse elszürkülése, elhomályosodása, amely a látás fokozatos, fájdalmatlan elvesztéséhez vezet (Süveges, 2010). 


\section{A Vision 2020 program húsz éve}

A látássérülés okai nagymértékben eltérnek a különböző gazdasági hátterű és egészségügyi ellátottsággal rendelkező országok, régiók esetén. 2002-ben a vakságot okozó legfőbb kórokok Afrikában a szürkehályog, a trachoma, a corneamegbetegedések, a zöldhályog, a folyami vakság és az A-vitamin hiányból származó látásromlás voltak. Ázsiában a szürkehályog, corneaelváltozások és a retinamegbetegedéségek, Latin-Amerikában és Kelet-Európában a szürkehályog, zöldhályog és diabéteszes retinopátia, Észak-Amerikában és Nyugat-Európában az időskori makuladegeneráció, a diabéteszes retinopátia és a zöldhályog (1. táblázat). Az ezredfordulón a vakság 60\%-át a szürkehályog és a fénytörési hibák, 15\%-át a trachoma és az A-vitamin hiány, valamint a folyami vakság okozta, szintén 15\%-ban volt felelős a vakságért a diabéteszes retinopátia és a zöldhályog. A vakság 10\%-át az időskori makuladegeneráció tette ki. A program indulásakor megfogalmazott egyik elérendő cél szerint, ha a gyógyítható (szürkehályog, fénytörési hibák) és a fokális (trachoma, A-vitamin hiány, folyami vakság) szembetegségek, valamint a gyermekkori látássérülést okozó kórokok felszámolása megtörténik, akkor 2020-ra a vakság 75\%-ban elkerülhető lesz (WHO, 2007).

\begin{tabular}{|c|c|c|c|}
\hline Afrika & Ázsia & $\begin{array}{c}\text { Latin-Amerika } \\
\text { Kelet- Európa }\end{array}$ & $\begin{array}{c}\text { Észak-Amerika } \\
\text { Nyugat-Európa }\end{array}$ \\
\hline szürkehályog & szürkehályog & szürkehályog & $\begin{array}{c}\text { időskori } \\
\text { makuladegeneráció }\end{array}$ \\
\hline trachoma & cornea elváltozások & zöldhályog & diabéteszes retinopátia \\
\hline cornea elváltozások & retina megbetegedéségek & diabéteszes retinopátia & zöldhályog \\
\hline zöldhályog & & & \\
\hline folyami vakság & & & \\
\hline $\begin{array}{c}\text { A-vitamin hiányból } \\
\text { származó látásromlás }\end{array}$ & & & \\
\hline
\end{tabular}

1. táblázat. A vakságot okozó legfőbb kórokok 2002-ben.

A Vision 2020 eredményeit lehetetlen felsorolni. Országonként, régiónként különböző módon, különböző eszközökkel igyekeztek a program célkitűzéseit megvalósítani az adott terület kóroki szempontjainak megfelelően. Az elmúlt húsz évben a minél eredményesebb múködés érdekében programok jöttek létre, illetve újabb és újabb akciótervek megfogalmazására került sor. Az egyik kiemelkedő program a 2000 óta minden év október második csütörtökjén megrendezésre kerülő Látás Világnapja (World Sight Day). Célja, hogy felhívja a figyelmet a vakságra és a látássérülésre, vagyis a látás megőrzése érdekében történő prevenció és a látásrehabilitáció fontosságára. 2005 óta minden évnek külön témája (címe) van, idén (2020-ban - a szerk.) ez a „Hope In Sight” (A látásba vetett remény) (WHO, 2018b; Németh, 2019).

A 2006. július 11-13. között, Genfben tartott stratégiai összejövetelén fogadta el a WHO a 2006-2011 közötti időszakra szóló stratégiai cselekvési tervet, az elkerülhető vakság felszámolásának előkészítéséről és bevezetéséről (Global Initiative for the Elimination of Avoidable Blindness: action plan 2006-2011). A cselekvési terv hívta fel először a figyelmet a nem korrigált fénytörési rendellenesség következtében létrejövő látássérülésre, ami abban az időben világszerte 153 millió embert érintett. Ebből legkevesebb 13 millió volt az 5-15 év közötti gyermek és 45 millió a munkaképes korú felnőtt (16-49 év). Kiemelésre került, hogy a vak személyek 82\%- 
a 50 évnél idősebb (pedig világviszonylatban az időskorú csoport az össznépesség csupán 19\%-át tette ki), illetve, hogy a látássérült személyek többsége nô. A cselekvési terv hangsúlyosan foglalkozott a súlyos fokú látássérülést okozó szembetegségek és kórokok prevenciójával, továbbá a humán erőforrás, az infrastruktúra és technológia fejlesztésével (WHO, 2007).

2009-ben a WHO 194 tagállammal és a nemzetközi partnerekkel közreműködve az elkerülhető vakság és látáskárosodás megelőzésére újabb cselekvési tervet dolgozott ki a 2009-2013 időszakra (Action Plan for the Prevention of Avoidable Blindness and Visual Impairment, 2009-2013.). A fö cél a már korábban elkezdett munka fokozása volt. Ennek oka, hogy 2010-re a föld népességéből 314 millió ember vált látássérültté, közülük 45 milliónyian vakká. A látássérülés $80 \%$-a azonban még mindig elkerülhető, vagy kezelhető lehetett volna. A látássérült személyek $90 \%$-a az alacsony, vagy közepes jövedelmű országokban élt. A vakság legfőbb okai a szürkehályog (39\%), a nem korrigált fénytörési rendellenességek (18\%), a zöldhályog (10\%), az időskori makuladegeneráció (7\%), a corneahomály (4\%), a diabéteszes retinopátia (4\%), a trachoma (3\%), a gyermekkori szembetegségek $(3 \%)$ és a folyami vakság $(0,7 \%)$ voltak. 2010-ben a becslések szerint míg a Skandináv országokban 5\%-os, addig Indiában 46\%-os volt a látássérülés prevalenciája (Laitinen et al., 2010; Murthy et al., 2010). Európában mintegy 28 millió látássérült ember élt, közülük több mint 2,7 millió volt vak (Pascolini \& Mariotti, 2011). A program - többek között - sürgette a helyi és globális szintű kutatások megvalósulását, a nemzeti akciókat és programokat, a tagállamok politikai, gazdasági és technológiai hozzájárulását a látásvédelem és látásrehabilitáció megvalósulásához, illetve a nemzetközi összefogást (WHO, 2010). A 2013-ban lejárt program után, a WHO új globális cselekvési programot dolgozott ki a következő öt évre „Universal Eye Health: Global Action Plan 2014-2019" címen. A cselekvési terv fô célja az elkerülhetô látássérülés előfordulásának 25\%-os csökkentése volt 2020-ig, továbbá a látássérültek számára a megfelelő rehabilitációs szolgáltatásokhoz való hozzáférések javítása. Az elkerülhető látássérülések közül ebben az idôszakban a szürkehályog és a nem korrigált fénytörési rendellenesség volt a két vezető ok, mely a látássérülés okainak 75\%-át tették ki. Mindkét szembetegség jóval gyakoribb volt az időskorú csoportok körében. A látássérülések 84\%-a az 50 évnél idősebb korosztálynál jelentek meg. A terv célul tűzte ki annak elérését, hogy ne történjen szükségtelen látásromlás, illetve, hogy azok, akik elvesztették látásukat, minél teljesebb életet élhessenek. További fő cél volt a szemészeti szolgáltatásokhoz való minél szélesebb körű hozzáférés biztosítása (WHO, 2013). Magyarország az utolsó két kezdeményezéshez csatlakozott.

A WHO 2015-ben készült felmérése szerint a világon 253 millió látássérült ember élt, közülük mintegy 36 millió volt a vak személy5. Míg Dél-Afrika egyes területein és Dél-Ázsiában az 50 év felettiek körében a vakság aránya több mint 4\% volt, addig a magas jövedelmú országokban ez az arány 0,5\% alatt maradt (Bourne et al., 2017) (2. táblázat).

\footnotetext{
${ }^{5}$ Az előrejelzések 2020-ra a vak személyek számának további növekedését várták, mintegy 38,5 millió főtt.
} 


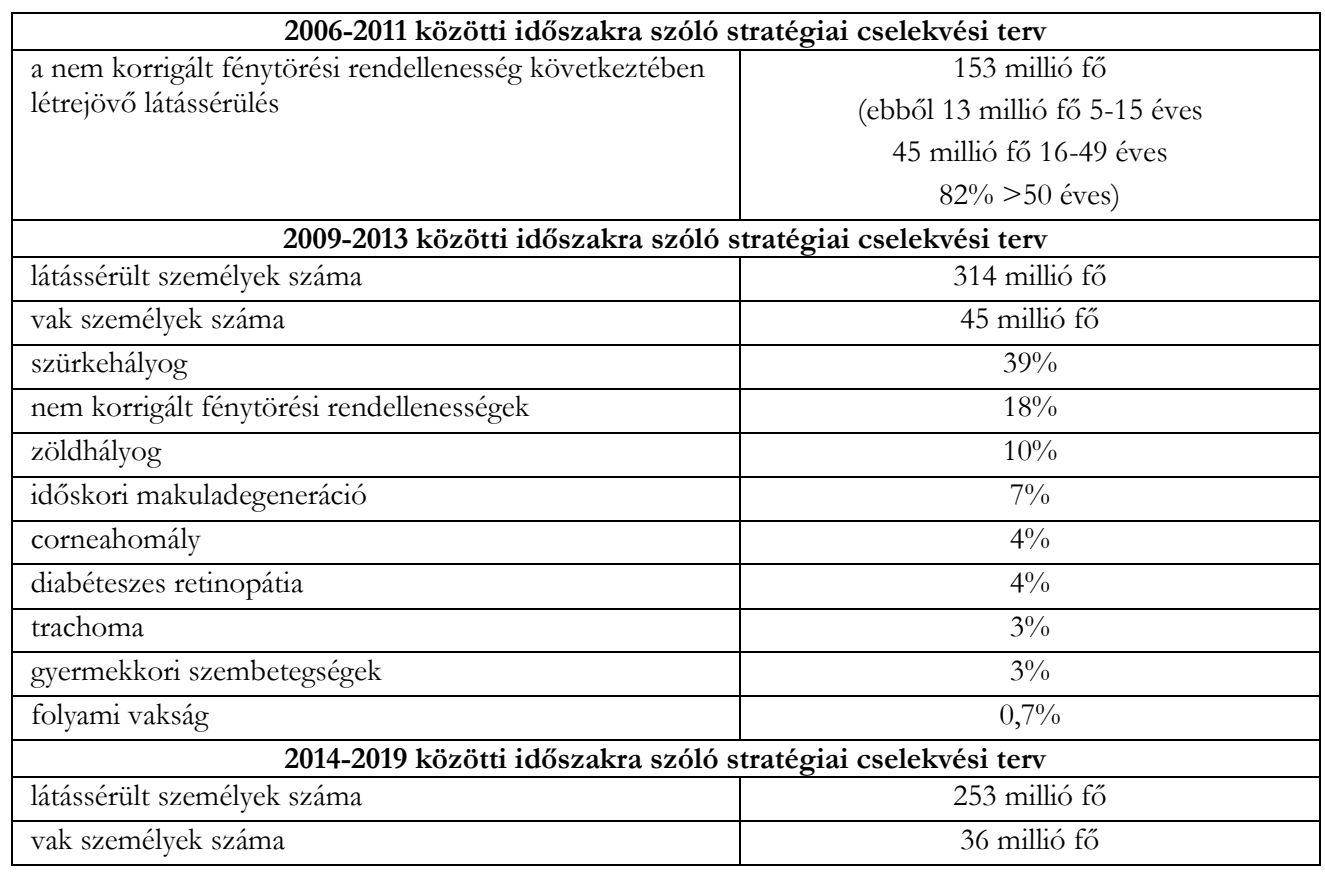

2. táblázat. A látássérülés prevalenciájának alakulása a stratégiai tervekhez kapcsolódóan.

A szembetegségek visszaszorításának eredményei közül két kórok okozta látássérülés trachoma, szürkehályog - sikeres csökkentését szeretném kiemelni. A Vision 2020 program az első öt évben a kórokozók és betegségek visszaszorításában a szürkehályog, a trachoma és a folyami vakság megelőzésére fókuszált, melynek célja a gyermekkori vakság, a nem korrigált fénytörési hibák és a látássérülés számának csökkentése volt. A vakságot okozó vezető fertőzés, a trachoma visszaszorításában nagy eredményt értek el a szakemberek. 2019-re 91\%-kal csökkent a trachomaveszélyeztetett emberek száma. Míg 2002-ben 1,5 milliárd fő volt kitéve a fertőzésnek, addig 2019re ez a szám 142,2 millióra csökkent. A trachoma utolsó stádiumában a vakság elkerülésére alkalmazott műtétekkel a trachoma okozta vakságot 68\%-kal sikerült visszaszorítani. Míg 2007-ben 8,2 millió fő vakult meg, addig 2019-re ez a szám 2,5 millió főre csökkent (Holland \& Resnikoff, 2019; WHO, 2019). Az 50 ország szolgáltatta adatok szerint a szürkehályog mútétek száma az 1988. évi 5 millióról, 2008-ra 15 millióra emelkedett. A mútéten átesett személyek 72\%-ának a látásélessége elérte a 0,1 vízusnál magasabb értéket, vagyis ők kikerültek a „,vakság” kategóriájából (Shah et al., 2011).

\section{A Vision 2020 Magyarországon}

A Magyar Szemorvostársaság 2001-ben kapcsolódott be a Vision 2020 programba, a Látás Napjáról való megemlékezéssel, szerkesztőségi közleménnyel, négy megyében végzett vaksági felméréssel ${ }^{6}$. A két évtized alatt hazánkban „több jelentős lépést sikerült elérni a vakság és

6 Részleteket lásd: https://semmelweis.hu/hirek/2006/10/12/a-latas-vilagnapja/ 
látáskárosodás megelőzése és a látásrehabilitáció fejlődése érdekében” (Németh, 2019, p. 110). Németh János professzor úr „Vision 2020 hazánkban” (Németh, 2019) címú cikkében részletesen beszámol a programban való sikeres részvételről: 1998-ban teljes körű országos felmérés történt a szemészeti fekvőbeteg-ellátásról. Az eredmények alapján hazánkat Kelet-Europában első helyre, a nyugati szintet elérők közé sorolták. A Vision 2020 program keretében három nagyszabású adatgyújtés is történt. Az 1996-2000 közötti években újonnan regisztrált adatokból (többek között) kiderült, hogy évente átlagosan 6060 újonnan regisztrált vak személy „várható”, illetve, hogy a fő vaksági vezető ok az időskori makuladegeneráció (22,7\%) és a diabéteszes retinopátia (15,6\%), húsz éves életkor alatt a koraszülöttek retinopátiája (ROP) (Németh, 2005). A 2005-2012 közötti időszak adatai alapján elmondható, hogy a vaksági okok eloszlása nagyon hasonló volt a tíz évvel korábbi eredményhez (Kiss \& Németh, 2013). 2015-ben populációalapú, reprezentatív, országos epidemiológiai felmérés történt nemzetközi standard metodika alkalmazásával a vaksági okok és a cukorbetegség megállapítására (Szabó et al., 2017; Szabó, 2018). A Látás Világnapjához hazánk 2001-ben csatlakozott, melyet azóta minden évben megrendez. Ennek keretében szűrések történtek, fórumok, előadások hangzottak el, kiállítások, sajtótájékoztatók szerveződtek. 2005 nyarán megalakult a Látássérültek Tanácsadó Szolgálata, melynek „célja, hogy a látássérültek a klinikáról közvetlenül eljuthassanak a rehabilitációs intézetekbe, iskolákba, szervezetekhez" (Németh, 2019, p. 112). A két évtized alatt emellett rehabilitációs munkacsoport alakult, együttműködési megállapodások születtek, 2007-ben „Látássérültek optikai rehabilitációja” szakrendelés kezdődött, 2008-ban „Látásrehabilitációs továbbképző tanfolyam” indult, illetve szintén ebben az évben „Csecsemő-Szem-Mentő Program”, mely „program keretében a koraszülöttek szemészeti célú szállításának számát drasztikusan sikerült csökkenteni. A telemetriás vizsgálatot 2010 októbere óta közel 9000 alkalommal végezték el. Az időben elvégzett szűrésnek és lézerkezelésnek köszönhetően egy koraszülött sem vesztette el látását.” (Németh, 2019, p. 113). A cukorbetegek szemfenéki telemedicinális programja 2008-ban indult. 2010 után szubretinális implantátumot kapott két beteg, illetve a Szemészeti Klinikán mikroperimetriai biofeedback látástréning mûködik. Szakmai irányelvek megfogalmazása történt a prevenció és a látásrehabilitáció témakörökben, szűrőprogramokat, látásrehabilitációs tanácsadást tartottak a szakemberek. 2016. május 27-én megalakult a Nemzeti Programbizottság a Jó Látásért. „A Bizottság fő célkitűzése a WHO „Universal eye health: a global action plan 2014-2019” hazai megvalósításának elősegítése, amely magában foglalja az elkerülhető vakság és látássérülés megelőzését, a jó látás megőrzését, illetve a látásrehabilitáció elérhetőségének fejlesztését és a vakok és gyengénlátó személyek számára a teljes élet lehetőségének biztosítását.” (Németh, 2019, p. 115). A különböző projektek mellett a hazai program egyik jelentős eredménye, hogy a látásrehabilitációs kapacitás a 2000. évi 40 főről két évtized alatt mintegy 600 főre emelkedett (Németh, 2019).

\section{A JELEN ÉS A JÖVÖ}

Az IAPB Vision Atlas 2020. évi adatai (The International Agency for the Prevention of Blindness, 2020) szerint napjainkban 1,1 millárd személy látássérült a világon, akik 90\%-a alacsony, vagy közepes jövedelmű országokban élnek. 43 millió fő vak, 295 millió fő látásélessége 0,02 és 0,3 közötti vízusértéket mutat (súlyos és mérsékelt látássérülés), 258 millió fő látássérülése enyhe, 
vagyis vízusa 0,3 és 0,5 közé esik. A 15 év alatti gyermekek közül világviszonylatban 90 millióan látássérültek. Közülük 2 millió gyermek vak, 30 millióan súlyos, illetve mérsékelt látássérülésben szenvednek, 58 millió gyermek enyhe fokban látássérült.

Napjainkban a látássérülést okozó leggyakoribb kórokok a fénytörési hibák (671 millió fő), a szürkehályog (100 millió fő), az időskori makuladegeneráció (8,1 millió fő), a zöldhályog (7,8 millió fő) és a diabéteszes retinopátia (4,4 millió fö) (3. táblázat).

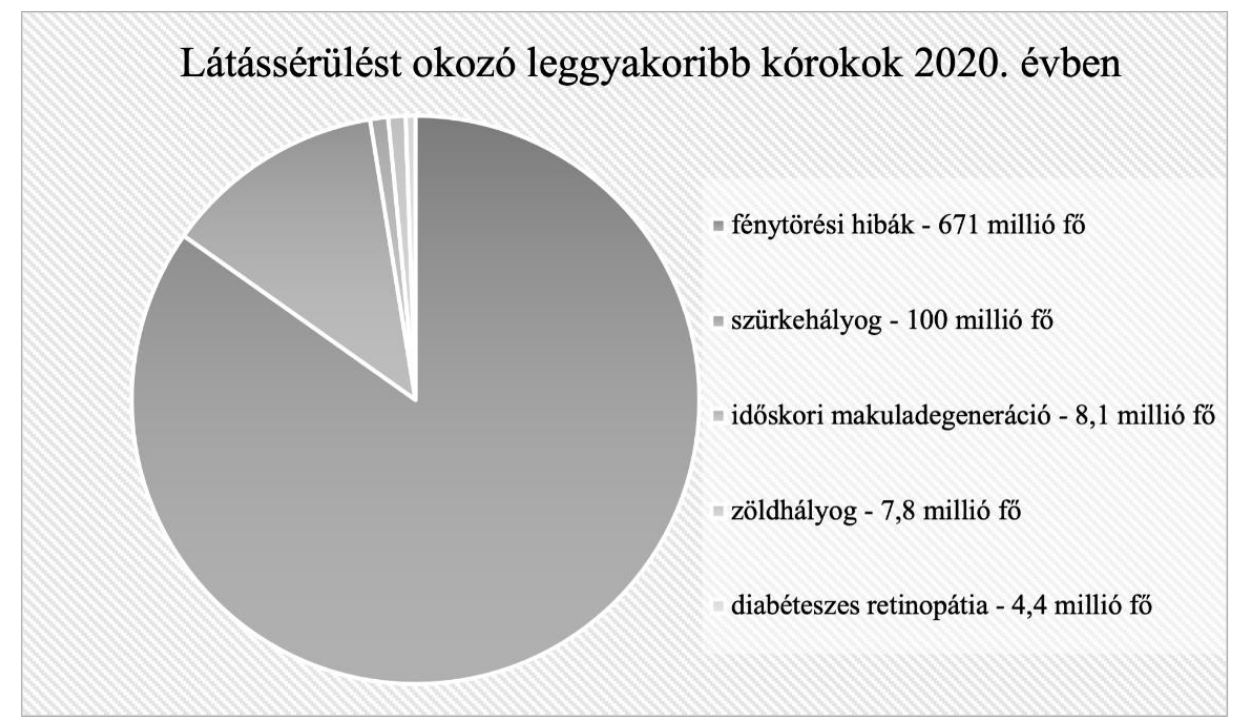

1. diagram. Látássérülést okozó leggyakoribb kórokok 2020. évben.

A számítások szerint 2050-re a jelenlegi 1,1 milliárd látássérülés 1,7 milliárdra növekszik majd. A látássérülések 90\%-a azonban elkerülhető lenne, ami 771 millió ember látásának megőrzését jelenti: 161 millió távollátásból adódó látássérülés, 100 millió szürkehályogból, 510 millió rövidlátásból származó látássérülést lehetne kivédeni.

\section{A jelenlegi akcióprogram - World Report on Vision}

A Vision 2020 program lezárásával azonban a 20 éves folyamat nem ért véget. A WHO 2019. október 8-án egy újabb nagyszabású programot hirdetett meg a látássérülés megelôzése és felszámolása céljából. A World Report on Vision nevű program 2019 és 2030 között zajlik. A WHO jelentése az eddigieknél jóval nagyobb mértékű látássérüléssel számol. Az adatok szerint világszerte legalább 2,2 milliárd látássérült személy élhet. Ebből 1 milliárd az olyan látássérülés, amely vagy megelőzhető lenne, vagy ellátatlan. Az 1 milliárd főbe beletartoznak azok a mérsékelt (vízus 0,1-0,3) és súlyos fokban (vízus 0,02-01) látássérült személyek, akik látássérülését a még nem diagnosztizált fénytörési rendellenesség okozza (123,7 millió fő), a szürkehályog (65,2 millió fő), a zöldhályog (6,9 millió fô), a cornearendellenességek (4,2 millió fö), a diabéteszes retinopátia (3 millió fö), a trachoma (2 millió fő) és a nem diagnosztizált és nem kezelt, rövidlátást okozó presbiópia (öregszeműség) (826 millió fő) (Bourne et al., 2017). A világ regionális különbségei 
erősen befolyásolják a szembetegségek természetét is. A távoli látássérülés az alacsony- és közepes jövedelmú országokban négyszer gyakoribb, mint a magas jövedelmú régiókban (Bourne et al., 2017). Míg a nyugat-, kelet- és középszubszaharai régiókban a nem diagnosztizált közeli látássérülések száma a látássérülések több mint 80\%-a, addig az észak-amerikai, ausztráliai, nyugateurópai és csendes-óceániai területeken ez az arány kevesebb mint 10 \% (Fricke et al, 2018). A gyengénlátás és a vakság vezető okai a nem korrigált töréshibákból származó látássérülés és a szürkehályog. A látássérült személyek többsége 50 év feletti. A népességnövekedés, illetve az időskor expanziója a látássérült személyek számának növekedését vetíti előre. A szembetegségek megjelenési formái szintén régiókhoz köthetőek. Például a szürkehályog gyakrabban fordul elő az alacsony és közepes jövedelmű országokban, mint a magas jövedelműeknél. A magas jövedelmű országok esetén azonban a diabéteszes retinopátia, a zöldhályog és az időskori makuladegeneráció a leggyakoribb kórok. Gyermekek esetén szintén nagy különbség van a régiók között. Míg az alacsony jövedelmú országokban a veleszületett szürkehályog a látássérülést okozó szembetegségek közül a vezető kórok, addig a közepes jövedelmű országok esetén ez a koraszülöttek ideghártyakárosodása (retinopathia prematurorum - ROP). A jelentés hangsúlyozza továbbá, hogy a nem korrigált távollátásból származó látássérülés $4 \mathrm{x}$ gyakoribb az alacsony és a közepes jövedelmú országokban, mint a magas jövedelmű régiókban. A látássérülés előfordulása nagyobb arányú a vidéken élők, az alacsony jövedelmú családok, a nők, az idősek, a fogyatékos személyek, az etnikai kisebbségek és bennszülött lakosság körében.

A mai napig sem helyi, sem globális szinten nem megoldott, hogy mindenki hozzájusson - és azonos minőségben jusson hozzá - azokhoz a szolgáltatásokhoz, amelyek biztosítják a megfelelő szemhigiéniát, a látássérülés megelőzését, a szembetegségek orvosi ellátását, valamint a rehabilitációs szolgáltatásokhoz való hozzáférést. A WHO a jelentésben javaslata:

- hogy a látásvédelem legyen az egyetemes egészségügyi ellátás szerves része;

- hogy minden ország ,integrált, személyközpontú” szemészeti szolgáltatást nyújtson, ami biztosítja az egyéni szükségetek szerinti, hosszútávú szemészeti ellátást;

- hogy szükséges a magas színvonalú kutatás elősegítése;

- hogy szükséges a változások nyomon követése és a fejlődés értékelése;

- hogy fontos a látásvédelem során a tudatosság növelése, az emberek és közösségek bevonása és erősítése.

A program célja, hogy segítséget nyújtson a tagországoknak, hogy azok képesek legyenek mérsékelni a látásvesztésből adódó terheket, és javítani a látássérült személyek életminőségét. Mindehhez szükséges a globális adatszolgáltatás a látásvesztés nagyságrendjéről, valamint annak megelőzéséről, kezeléséről és rehabilitációjáról (WHO, 2019).

\section{ÖSSZEGZÉS}

A Vision 2020 1999-ben indult világméretű program, melynek fő célja a látássérülés minél nagyobb mértékű felszámolása volt, nem előzmények nélkül jött létre. A WHO már a 20. század közepétől folyamatosan szervezett akciókat a vakság felszámolására. A két évtizedes program indulását globális adatbázis, a látással és látássérüléssel foglalkozó szervezetek működése, nemzetközi 
együttműködések, az alapfinanszírozás megléte, és egyre nagyobb számú, a programhoz csatlakozó ország részvétele segítette. A világméretű akció feladata nem volt könnyű. A világ különböző régiói más-más gazdasági szinten állnak, és emiatt eltérő egészségügyi háttérrel rendelkeznek. Mindez nem csupán a területenként előforduló szemészeti kórokok eltérő jellegét vonja maga után, de a kórformák különböző prevalenciáját is jelenti. A program a kórformák visszaszorításában jelentős eredményeket ért el a szürkehályog és a trachoma szembetegségek esetén, amivel emberek tömegeit mentette meg a vakságtól. Az elkerülhető látássérülés előfordulásának csökkentése érdekében a program hangsúlyosan részt vett a humán erőforrás, az infrastruktúra és technológia fejlesztésében.

A húsz év során a WHO a Vision 2020 programon belül több cselekvési terv meghirdetésével igyekezett minél több eredményt elérni az elkerülhető vakság és látáskárosodás megelőzésében és felszámolásában.

Hazánk 2001-ben csatlakozott a Vision 2020 programhoz, mely ,sikerekben gazdag. Széleskörű összefogást és közös munkát hozott létre a vakság és látássérülés elleni küzdelemben és a látásrehabilitációban" (Németh, 2019, p. 116). Mivel hazánkban is - a populáció változását követve - növekszik a felnőtt- és időskorban történő súlyos fokú látássérülések száma, ezért szükséges, hogy a rehabilitációs munka egyre nagyobb jelentőséget, teret és szerepet kapjon.

2020-ra a globális népességnövekedés miatt a látássérült személyek becsült száma több mint 2 milliárd fö, azonban a látássérülés fele megelőzhető lenne. A látássérült személyek $90 \%$-a szegény. Nagymértékben növekedett az időskorú népesség száma, így az időskorú látássérülés aránya is magas. A gyengénlátás és a vakság vezető kórokai a 20 év alatt megváltoztak, azonban a regionális különbségek sem az eltérő kórokok, sem az egészségügyi ellátáshoz való hozzáférés tekintetében nem tűntek el. A WHO 2019 októberétől új akcióprogram keretében - World Report on Vision folytatja a súlyos fokú látássérülés megelőzését és visszaszorítását.

\section{IRODALOMJEGYZÉK}

World Health Organization \& African Programme for Onchocerciasis Control. (1996). Programme document: African Programme for Onchocerciasis Control (APOC). African Programme for Onchocerciasis Control. https://apps.who.int/iris/handle/10665/276052

Benton B. (1998). Economic impact of onchocerciasis control through the African Programme for Onchocerciasis Control: an overview. Annals of Tropical Medicine and Parasitology, 92(1), S33-S39. https://doi.org/10.1080/00034989859537

Bourne R. R. A., Flaxman S. R., Braithwaite T., Cicinelli M. V., Das A., Jonas J. B., et al. (2017). Vision Loss Expert Group. Magnitude, temporal trends, and projections of the global prevalence of blindness and distance and near vision impairment: a systematic review and meta-analysis. Lancet Global Health, 5(9), 888-897. https://doi.org/10.1016/s2214-109x(17)30293-0

Fricke T. R., Tahhan N., Resnikoff S., Papas E., Burnett A., Suit M. H., Naduvilath T., \& Naidoo K. (2018). Global Prevalence of Presbyopia and Vision Impairment from Uncorrected Presbyopia: Systematic Review, Meta-analysis, and Modelling. Opbthalmology, 125(10), 1492-1499. https://doi.org/10.1016/i.ophtha.2018.04.013 
Holland P. \& Resnikoff S. (2019). Beyond VISION 2020: universal eye health coverage and the elimination of trachoma. Common Eye Health, 32(107), 60.

Laitinen A., Laatikainen L., Härkänen T., Koskinen S., Reunanen A. \& Aromaa A. (2010). Prevalence of major eye diseases and causes of visual impairment in the adult Finnish population: a nationwide populationbased survey. Acta Ophthalmologica, 88, 463-471. https://doi.org/10.1111/j.1755-3768.2009.01566.x

Kiss H. \& Németh J. (2013). A vakság okai Magyarországon. Szemészet, 150(3), 21-28.

Murthy G. V. S., Vashist P., John N., Pokharel G. \& Ellwein L. B. (2010). Prevelence and Causes of Visual Impairment and Blindness in Older Adults in an Area of India with a High Cataract Surgical Rate. Ophthalmic Epidemiology, 17(4), 185-195. https://doi.org/10.3109/09286586.2010.483751

Németh J., Frigyik A., Vastag O., Göcze P., Pető T. \& Elek I. (2005). Adatszolgáltatók: Vaksági okok Magyarországon. Szemészet, 142, 127-133.

Németh J. (2019). Vision 2020 hazánkban. Szemészet, 156(3), 109-118.

Pascolini D. \& Mariotti S. P. (2011). Global estimates of visual impairment: 2010. British Journal of Ophthalmology, 96(5), 614-618. https://doi.org/10.1136/bjophthalmol-2011-300539

Resnikoff S. \& Pararajasegaram R. (2001). Blindness prevention programmes: past, present, and future. Bulletin of the World Health Organization, 79 (3), 222-226.

Shah S. P., Gilbert C. E., Razavi H. E., Turner L \& Lindfield R. J. (2011). Preoperative visual acuity among cataract surgery patients and countries' state of development: a global study. Bulletin of the World Health Organization, 89(10), 749-756. https://doi.org/10.2471/blt.10.080366

Süveges, I. (2010). Szemészet. Medicina Könyvkiadó Zrt., Budapest. ISBN: 9789632262703.

Szabó D., Tóth G., Sándor G. L., Pék A., Lukács R., Szalai I., Tóth G. Zs., Papp A., Nagy Z. Zs., Limburg H. \& Németh J. (2017). A vakság okai Magyarországon. A RAAB-metodika első hazai alkalmazása. Szemészet, 154(3), 119-125.

Szabó D. (2018). A vakság és látásromlás elófordulása és okai hazánkban, a diabéteszes retinopátia telemedicinális szürése. Doktori értekezés. Semmelweis Egyetem Klinikai orvostudományok Doktori Iskola, Budapest.

The International Agency for the Prevention of Blindness. (2020). Vision Atlas. https://www.iapb.org/learn/vision-atlas/Letöltve: 2020. 10. 18.

Thylefors B., Négrel A. D., Pararajasegaram R. \& Dadzie K. Y. (1995). Global data on blindness. Bulletin of the World Health Organization, 73(1), 115-121.

World Health Organization (1995). Onchocerciasis and its control. Report of a WHO Expert Committee on Onchocerciasis Control. Geneva, (WHO Technical Report Series, No. 852). https://apps.who.int/iris/bitstream/handle/10665/37346/WHO TRS 852.pdf?sequence $=1$ Letöltve: 2020. 10. 18.

World Health Organization (1999). OCP: World Health Organization Control Programme, 1974-1999. Geneva. https://apps.who.int/iris/bitstream/handle/10665/275602/275602-eng.pdf Letöltve: 2020. 10. 18.

World Health Organization (2007). Global Initiative for the Elimination of Avoidable Blindness Action Plan 2006-2011. https://www.who.int/blindness/Vision2020 report.pdf Letöltve: 2020. 10. 20.

World Health Organization (2010a). Action Plan for the Prevention of Avoidable Blindness and Visual Impairment, 2009-2013. https://www.iapb.org/learn/resources/who-action-plan-for-theprevention-of-avoidable-blindness-and-visual-impairment-2009-2013/Letöltve: 2020. 10. 20.

World Health Organization. (2010b). WHO | What is VISION 2020? https://www.who.int/blindness/partnerships/vision2020/en/ Letöltve: 2020. 10. 20. 
World Health Organization (2013). Universal Eye Health: A Global Action Plan 2014-2019. Geneva, Switzerland. https://www.who.int/blindness/actionplan/en/ Letöltve: 2020. 10. 20.

World Health Organization (2018a). The WHO Alliance for GET2020. https://www.who.int/trachoma/partnership/en/ Letöltve: 2020. 10. 20.

World Health Organization. (2018b, October 8). World Sight Day. https://www.who.int/blindness/world sight day/en/ Letöltve: 2020. 10. 20.

World Health Organization. (2020, October 8). Blindness and visual impairment. https://www.who.int/en/newsroom/fact-sheets/detail/blindness-and-visual-impairment Letöltve: 2020. 10. 20.

World Health Organization. (2019). World report on vision. https://www.who.int/publications/i/item/worldreport-on-vision Letöltve: 2020. 10. 20.

\title{
Vision 2020 - Right to Sight
}

\section{A twenty-year global program for vision protection}

\begin{abstract}
This article presents the background of the WHO Vision 2020 program and the path leading to its implementation. It provides insight into the changes in the pathogenesis and prevalence of visual impairment that have occurred worldwide as a result of the program. During the twenty-year long action, action plans organized to prevent avoidable blindness and visual impairment contributed greatly to the success of the program.

In addition to the international results, the article also briefly presents the Hungarian research, programs and results. However, the struggles to eradicate avoidable blindness and visual impairment by the year of 2020 are not over. Faced with new focal points and a growing global population, steps to eliminate blindness and visual impairment will continue.
\end{abstract}

Keywords: WHO, Vision 2020 - Right to Sight, World Riport of Vision, blindness, visual impairment, prevention 